\title{
Alkaline Ceramidase 3
}

National Cancer Institute

\section{Source}

National Cancer Institute. Alkaline Ceramidase 3. NCI Thesaurus. Code C103898.

Alkaline ceramidase 3 ( $267 \mathrm{aa}, \sim 32 \mathrm{kDa}$ ) is encoded by the human ACER3 gene. This protein is involved in the synthesis of phytosphingosine. 